\title{
THE NOBLE JIHAD
}

Jose Maria de Nazareno

\section{About the Author}

Jose Maria de Nazareno holds a Ph.D. in Philippine Studies from the University of the Philippines-Diliman. In his student days at the University of Sto. Tomas, he became Editorin-Chief of the Journal of Theology, and Witness Section Editor of the Varsitarian, the official student organ. He received the Inter Nos lifetime achievement award in 2011 from the same university on the occasion of its quadricentennial. Author of six books, he is a recipient of The Catholic Mass Media Award (CMMA) for his book Sick Situations and Pastoral Heart (Makati: St. Pauls Philippines, 2012). He teaches Theology at De La Salle University-Manila and Philosophy at San Carlos Seminary in Makati. A writing fellow of the 54th UP National Writers' Workshop, he writes mainly for the love of country and greater glory of God. 
The young Moro writers of Rays of the Invisible Light, edited by Gutierrez Mangansakan II, are the living proofs of the validity of Jose Rizal's assertion that the young are the hope of this nation in this increasingly fluid, pluralistic, urbancentered, postmodern world. Their indomitable collective spirit is defined and enlightened by the "noble jihad," Mangansakan's coinage in the Preface, whose inexhaustible meaning is conceived, incubated, and finally born in this book.

The Quran itself prescribes that Jihad which literally means "Holy Struggle" cannot be limited to waging a physical war against infidels. It could be accomplished through a peaceful preaching of Islam. The Quran, 25:52, states: "Therefore listen not to the Unbelievers, but strive against them with the utmost strenuousness." The Quran, 16, 125 further clarifies: "Invite (all) to the way of thy Lord with wisdom and beautiful preaching; and argue with them in ways that are best and most gracious: For thy Lord knoweth best, who have strayed from His Path, and who receive guidance."

In using the noble jihad, Mangansakan explains that the jihadists in this anthology are fighting for enlightenment-risking their good Islamic standing in the struggle to collapse the walls of prejudices among people of various religious persuasions-using the pen's (read: computer's) might.

The young, reckless, literary jihadists' entries in this anthology depict a truthful representation of their struggles, unmindful of the negative self-image that they may project in their readers' minds in exposing, for instance, the dirty Moro business practices, among other self-deprecating customs.

The three poems by Mohammad Nassefh Macla, in which he depicts the nostalgic memories of the good old days, the dreams of a better future, and the encouragement to wage war to achieve peace and realize one's dreams, serve as an introduction to this anthology's three-act structure.

Its rising action is fluidly continued by the disclosure of the jihadists' most secret and darkest emotions. An example is Pearlsha Abubakar's "Studying A Triangle and Playing Oido," which reveals the roughly amorous edge of Islamic polygamy's love triangle, shattering the hearts of two women and their children.

Its induced pain is intensified by Arifah Macacua Jamil's "Sakeenah," depicting the emotional mess of divorce caused by messy factors: Katao (sorcery), hormonal imbalance, fate, lack of blood relations. 
This rising tension would be brought to a climax by Zakiyyah Sinarimbo's "Of Remembering," which is all about a grandma's death and funeral, showing Islamic customs, beliefs, superstitions, rituals of saying goodbye.

As in a well-crafted plot of a novel, what follows after the climax, death in this anthology, is the falling action leading to the plot resolution which is Reinna Bermudez's "The Road to Sulgah," whose opening line introduces another possible conflict: A woman who does not allow her husband to take up a second wife will not find her way to Paradise. What can the feminists say about this statement of Islamic faith? Rather than giving answers, this piece raises more questions: How could the road to heaven, sulgah, be paved with so much pain? Or how could another woman, a duaya, pave the road to heaven with so much pain? In this piece, the brave jihadist of an author, fighting the battle within the Muslim custom of polygamy, even dares to question the purity of the intention of a man who, in having a second wife, could take advantage and even manipulate women's Islamic faith for his own chauvinistic ends.

The falling action of the plot leading to conflict resolution continues with Kristine Ong Muslim's "Levitation" which describes the cataclysmic end of the world. Loren Hallilah I. Lao, another brave jihadist unintimidated by public opinion, delves into a primitive and politically incorrect practice of slavery in "Son of Sugoon."Heartlessness, ruthlessness, and violent oppression end in a slave boy's horrible demise. In this conflict resolution, the slave boy's untimely death is seen as the road to heaven-the ultimate freedom. The jihadist raised a perplexing question in the readers' minds: Death or slavery?

The coming-home theme in this falling action still leading to conflict resolution continues with Diandra-Ditma Macarambon's "Rotten Fruits." Going back to her mom's ancestral home in Padian after more than 15 years, the jihadist recognizes the dramatic changes in her place of birth marred by pollution and garbage. Exposing rotten reality, this brave jihadist is not afraid to tell the world of the Muslim vendor's rotten tricks. In her homecoming, the jihadist was welcomed by the huge tarpaulin with the picture of the local politician, the eldest daughter of the dishonest fruit vendor selling rotten fruits.

In this journey towards conflict resolution, the road to heaven is paved with temptations. Janesa Mariam G. Ladjiman's "Haram” raises the age-old question: Why is it that when something is prohibited, it becomes more appealing? If eating ice-cream were sinful, it would have been as enticing as the fruit of the forbidden tree in the Old Testament. For Muslims, pork is prohibited. Not wearing purung, this jihadist hides her identity to be able to eat pork. For eating pork and not 
wearing purung, is she a good Muslim? There is something more circumspect in raising this question. The undercurrent is religious insurgency.

Rizal was not a good son of Spain when the country was under the colonial heels. Being bad, or rebellious in the lexicon of the Spanish authorities, made Rizal our hero today. Does it mean that heroism lies in being a rebel? Jesus of Nazareth was a bad Jew - that was why he was crucified. His rebelliousness against the Jews, leading to his crucifixion, was the condition of possibility for the revelation of his messianic role. What would make this inward jihadist?

In "Vignettes Unveiled and Brought to Light," Datu Shariff Pendatun III reveals his mixed ancestry which helps in advancing this noble jihad's mission to take down racial and religious wall. His maternal ancestors are Catholics. His grandmother is devoted to Our Lady of the Miraculous Medal. His Muslim grandfather's sister is a faith healer.

This search for conflict resolution rightly ends with Datu Shariff Pendatun III's "Destination" Recognizing his varied ancestral, educational, cultural, and religious background, he has come to his destination of choice that is Mindanao. He has chosen Islam for his religion, for the continuity of jihad's mission.

I consider Sahara Alia Silongan's "Haraam," a poem about sinful love called heaven, and Gutierrez Mangansakan II's "Excerpt from MORO2MRW," an excerpt of a film script depicting a longing for a better Moro world of tomorrow, as the anthology's epilogue. On the whole, this anthology stretches the noble jihad's meaning beyond its common understanding into a mission to destroy barricades dividing humanity by challenging Islamic taboos, exploring unchartered territories, and opposing religious fanaticism, the mother of blasphemous violence and terrorism.

Allowing me to write about the works of these young jihadists is a profound statement that, indeed, the noble jihad of the educated is mightier than the sword of the ignorant. Allowing me to comment on these all-Moro artistic works is an affirmation of the noble jihad's mission to enlighten the dark force of prejudices instigating religious war.

For allowing me to enter into the Moro literary world, these writer-jihadists deserve my admiration for their bravery. I admire more the unintended fruit of their bravery which is inter-religious dialogue-a relatively new religious domain. For while I am Mangansakan's co-fellow at the 54th UP National Writers' Workshop, I am also a Catholic priest whose voice among the Islamic writers' chorus is like a swine's meat-Haram. 